\title{
MICROSCOPIC APPEARANCE OF URINE IN THE NEONATAL PERIOD
}

BY

\author{
J. S. LAWSON and A. S. HEWSTONE \\ Royal Children's Hospital, Melbourne
}

(RECEIVED FOR PUbLICATION JANUARY 20, 1964)

The absence of clinical signs in the newborn infant makes the diagnosis of urinary tract infection and other renal disease difficult. Urine cell counts are an important aid to diagnosis of infection because uncontaminated urine for culture is particularly difficult to obtain in the newborn. However, the types and numbers of cells in the urine of normal newborn infants are not recorded in standard texts. This report describes the microscopic examination of urine from a series of babies born consecutively at an obstetric hospital.

\section{Material and Methods}

Examinations were carried out on 217 specimens of urine, which were collected in adhesive plastic bags ('paediatric urine collectors') on the first, second, fourth, sixth, and eighth days of life. The urine was refrigerated from the time of collection until the time of examination. Stansfeld (1962) has shown that in an acid urine, below $p \mathrm{H} 6 \cdot 8$, cells will survive for 48 hours without significant change in their numbers. Examination of the uncentrifuged well-shaken specimens was made within 24 hours of collection. $p \mathrm{H}$ values were recorded just before examination, and those specimens with $p \mathrm{H}$ values above 6 were not included in the series. The cells were counted on a Neubauer counting chamber, counting 5 large squares and multiplying the figure by 2 . This was considered more suitable for this study than counting 2 large squares and multiplying by 5 as recommended by Stansfeld (1962).

The various types of cells seen in the urine were identified and counted. Of the 217 examined 61

TABLE 1

161 SPECIMENS FROM MALE INFANTS

\begin{tabular}{c|c|c|c|c}
\hline \multirow{2}{*}{ Cells/c.mm. } & \multicolumn{2}{|c|}{ Epithelial Cells } & Leucocytes & $\begin{array}{c}\text { Red } \\
\text { Blood } \\
\text { Cells }\end{array}$ \\
\cline { 2 - 3 } & Squamous & Round & & 5 \\
\hline $0-5$ & 48 & 15 & 26 & 1 \\
$5-10$ & 20 & 6 & 5 & 2 \\
$10-20$ & 10 & 0 & 1 & 2 \\
$>20$ & 4 & 2 & 3 & 5 \\
\hline
\end{tabular}

specimens contained no cells at all; in the remainder from 1 to 4 types were present.

\section{Results}

The results (Tables 1 and 2) were compiled by recording the number of cells of each type seen in every specimen.

Uric acid crystals were seen in 8 specimens, and a granular cast was seen in one.

The pattern of cells present in the urine of 1-dayold infants tended to continue during the first week of life although in fewer numbers. However, there were some exceptions to this: the urine of a 4-day-old baby contained 150 leucocytes/c.mm. although previous and later specimens contained none, and the urine of a 6-day-old infant contained 12 red blood cells/c.mm. although none were seen before or after. There was no correlation between the appearance of red blood cells and leucocytes. In only one specimen of urine were both types of cell present together. No cause was found for the presence of leucocytes in numbers greater than $10 /$ c.mm. except for a baby girl with vaginal thrush.

The number of epithelial cells was much higher than that found in older children. Of the specimens, $1.8 \%$ had more than 10 red blood cells/c.mm. and $5 \%$ had more than 10 leucocytes/c.mm. The $5 \%$ of specimens containing more than 10 leucocytes/c.mm. is less than the $8 \%$ in older children found by Stansfeld and Webb (1953).

TABLE 2 70 SPECIMENS FROM FEMALE INFANTS

\begin{tabular}{c|c|c|c|c}
\hline \multirow{2}{*}{ Cells/c.mm. } & \multicolumn{2}{|c|}{ Epithelial Cells } & Leucocytes & $\begin{array}{c}\text { Red } \\
\text { Blood } \\
\text { Cells }\end{array}$ \\
\cline { 2 - 3 } & Squamous & Round & & 0 \\
\hline $0-5$ & 9 & 14 & 15 & 2 \\
$5-10$ & 10 & 2 & 5 & 1 \\
$10-20$ & 11 & 3 & 4 & 0 \\
$>20$ & 30 & 1 & 5 & \\
\hline
\end{tabular}




\section{Summary}

It was found that $95 \%$ of specimens of urine from normal newborn infants had less than 10 leucocytes /c.mm. and $98 \%$ had less than 10 red blood cells/ c.mm. It is suggested that when more than 10 leucocytes or more than 10 red blood cells/c.mm. are found in specimens of urine from newborn infants for two or more days further investigation is warranted. The appearance of these cells on one day only during the first week of life is probably a normal finding.

We would like to thank Dr. Laver and the nursing staff of the Royal Women's Hospital, Melbourne, for their help with this study.

\section{REFERENCES}

Stansfeld, J. M. (1962). The measurement and meaning of pyiria. Arch. Dis. Childh., 37, 257.

- and Webb, J. K. G. (1953). Observations on pyuria in children. ibid., 28, 386. 